\title{
Livestock Feeding Practices Followed by Dairy Farm Women in Belagavi District of Karnataka
}

\author{
J. S. Bhoomika* and Geeta P. Channal \\ Department of Extension and Communication Management, College of Community science, \\ University of Agricultural Sciences, Dharwad-580005, Karnataka, India \\ *Corresponding author
}

\section{A B S T R A C T}

Keywords

Livestock, Mineral

mixture,

Concentrate,

Scientific feeding

practices

Article Info

Accepted:

15 January 2021

Available Online:

10 February 2021
The present study is undertaken to know the feeding pattern followed by dairy farm women in Belagavi district. The study is an "survey based research" conducted in 2019-20. The respondents were selected proportionately from Raybag and Gokak taluks, further two villages from each taluk were selected randomly, thus constituting 120 dairy farm women as a sample size for the study by employing proportionate random sampling technique. The primary data was collected by personal interview method with the help of pre-tested structured interview schedule and data was analyzed using suitable statistical tools. The investigation found that large majority $(89.17 \%)$ of the respondents practiced stall feeding method, $80.84 \& 67.50$ per cent of dairy farm women used to provide water and concentrate feed twice a day, 55.83 per cent fed purchased fed twice a day followed by 51.66 per cent of them were given fodder more than three times in a day, almost half $(49.16 \%)$ of the dairy farm women fed mineral mixture, $49.17 \& 50.83$ per cent of respondents practiced chaffing and direct feeding of green \& dry fodder respectively and 31.67 per cent of the dairy farm women were given home made feed.

\section{Introduction}

Mixed cropping and livestock rearing is traditionally influenced in India. Integration of crop + livestock systems is evident especially in medium and small holders farming systems (Nagaratna et al., 2003). A strong integration of livestock rearing and agriculture has enormous potential in improving socio- economic conditions of rural communities especially women, landless, marginal and small land holders, by generating gainful employment throughout the year and supplementing the family income. Keeping livestock is a valuable asset which withstands crop failure during natural calamities. Improving productivity of the animals is directly correlated with feeding pattern and 
local cropping pattern. The major source of livestock feed in mixed farming are primarily crop residues. A dual purpose crops provides feed in the form of crop residues. The dual purpose crops including rice, wheat, sorghum, pearl millet, ragi, maize and pulses residues which are important source of feed and assumed greater importance in decreasing level of feed deficit, which constitutes 40-60 per cent of total dry matter intake (Parthasarthy and Hall, 2003).

Livestock sector in India makes up a colossal number of 535.78 million animals, representing more than 20.00 per cent of the livestock population in the world $\left(20^{\text {th }}\right.$ livestock census, 2019). India had estimated a total milk production of 176.27 MT and backed first position in the world (National dairy development board, statistics, 2017). But the productivity of the milch animals is conspicuously low compared to developed countries. The low average milk production of milch animals in the country is attributed to various reasons like feeding less than the requirement, feeding imbalanced ration which contains energy, protein, minerals and vitamins either in excess proportion or shortage relative to nutrient requirement and generally fed crop residues which contains less nutrients with one or two provincially obtainable concentrate feeds such as oil seed cakes or home made feeds without knowing the recommended requirements of livestock. This leads the way to substandard growth, retards maturity and lowers the productiveness than optimum after reaching reproductive age. So right combination of timely and sufficient quantity of feeding play a vital role in improving productivity of animals and economizing the cost of milk production, Therefore it is necessary to understand local livestock feeding practices and cropping pattern followed by respondents in the region to formulate suitable policies and implications for policy makers. So considering above fact the study entitled "Livestock Feeding Practices Followed by Dairy farm women in Belagavi district of Karnataka" carried with a specific objectives to know the local feeding pattern and cropping pattern.

\section{Materials and Methods}

The current investigation was undertaken in Belagavi district of Karnataka during 2019-20. The district is selected purposively because it has highest livestock population in the state. Further, among ten taluks, two taluks were selected based on highest women co-operative members according to secondary information collected from BEMUL. Later four villages were randomly selected in the district viz., Neeralakudi and Mugholkhod from Raybag, Khanatti and Bisankoppa from Gokak and 30 dairy farm women were selected from each village randomly using proportionate random sampling technique, thus forming 120 respondents as a sample size for the study. The survey based design was employed to collect the data by personal interview method using pretested structured interview schedule. Further collected data was coded, analyzed and tabulated using frequency and percentage.

\section{Results and Discussion}

\section{Daily livestock feeding pattern followed by dairy farm women}

The information in the Table 1 shows that 89.17 per cent of the dairy farm women practice stall feeding only and 10.83 per cent of them practice stall feeding + grazing and none of them practice only grazing for their livestock. This is due to lack of open grazing lands in villages, non-availability of palatable grasses in otherwise available grazing lands, rearing of crossbred animals, availability of fodder in the households in the form of cultivated fodder and crop residues could be the reasons for the above finding. The findings 
are similar with the studies of Sabapara (2016) and Jadav (2018). Nearly half (49.16\%) of the dairy farm women were using mineral mixture to feed their livestock. This is justifiable as mineral mixture needs to be given in small quantity but it has profound effect on animal health. So there is a need to educate remaining respondents to follow the practice of feeding mineral mixture. The results are in line with findings of Jadav (2018).

About 68.00 per cent $(67.50 \%)$ of the respondents fed livestock twice a day with concentrate feed. Dairy farm women of the study area are members of milk co-operative society. This society sells feed to its members on credit basis. This might have been viewed as not only convenient but also advantageous by the farm women as is reflected from the results of the present study. About 33.00 per cent of the respondents used concentrate feed only once in a day and this could be because of less number of livestock, poor knowledge as well poor economic status of the farm household.

With regard to type of feeds given to animals, 55.83 per cent of the respondents were providing purchased feed and this might be due to its availability in milk co-operative society. However, 31.67 per cent used homemade concentrate feed and only 12.50 per cent were providing both purchased + home made cattle feed to the livestock.

Table.1 Daily livestock feeding pattern followed by dairy farm women

\begin{tabular}{|c|c|c|c|c|}
\hline SI no. & Particulars & Categories & Frequency & Percentage \\
\hline \multirow[t]{2}{*}{1.} & \multirow[t]{2}{*}{ Feeding system } & Stall feeding only & 107 & 89.17 \\
\hline & & $\begin{array}{l}\text { Stall feeding + } \\
\text { Grazing }\end{array}$ & 13 & 10.83 \\
\hline 2. & $\begin{array}{l}\text { Feeding of mineral } \\
\text { mixture }\end{array}$ & Once & 59 & 49.16 \\
\hline \multirow[t]{2}{*}{3.} & \multirow{2}{*}{$\begin{array}{l}\text { Feeding of } \\
\text { concentrate feeds }\end{array}$} & Once & 39 & 32.50 \\
\hline & & Twice & 81 & 67.50 \\
\hline \multirow[t]{3}{*}{4.} & \multirow[t]{3}{*}{ Types of feeds used } & Home made & 38 & 31.67 \\
\hline & & Purchased feed & 67 & 55.83 \\
\hline & & $\begin{array}{c}\text { Home made + } \\
\text { purchased }\end{array}$ & 15 & 12.50 \\
\hline \multirow[t]{3}{*}{5.} & \multirow{3}{*}{$\begin{array}{l}\text { Number of times } \\
\text { fodder given }\end{array}$} & Twice & 25 & 20.84 \\
\hline & & Thrice & 33 & 27.50 \\
\hline & & More than thrice & 62 & 51.66 \\
\hline \multirow[t]{3}{*}{6.} & \multirow{3}{*}{$\begin{array}{l}\text { Number of times } \\
\text { water given }\end{array}$} & Twice & 97 & 80.84 \\
\hline & & Thrice & 19 & 15.83 \\
\hline & & More than thrice & 4 & 03.33 \\
\hline
\end{tabular}

* Home made ingredients- Broken grains (Maize, Jowar, Wheat, Rice, Horsegram, Jaggery)

* Purchased feed - cotton seed cake, groundnut seed cake, pellets. 
Table.2 Cropping pattern of the farms owned by landholders

$\mathrm{n}=120$

\begin{tabular}{|c|c|c|c|}
\hline SI no. & Crops cultivated & Frequency & Percentage \\
\hline \multicolumn{4}{|c|}{ 1. Kharif } \\
\hline a. & Maize & 97 & 80.33 \\
\hline b. & Turmeric & 57 & 47.50 \\
\hline c. & $\begin{array}{l}\text { Other vegetable (chilli, fenugeek, cabbage, } \\
\text { cauliflower, tomato } \\
\text { Knolkhol, avare, cluster beans, ladies finger) }\end{array}$ & 11 & 09.17 \\
\hline d. & Groundnut & 5 & 04.16 \\
\hline e. & Sorghum & 3 & 02.50 \\
\hline \multicolumn{4}{|c|}{ 2. Rabi } \\
\hline a. & Wheat & 61 & 50.83 \\
\hline b. & Garlic & 58 & 48.33 \\
\hline c. & Maize & 34 & 28.33 \\
\hline d. & Bengal gram & 17 & 14.16 \\
\hline e. & Safflower & 10 & 08.33 \\
\hline f. & Ground nut & 8 & 06.66 \\
\hline g. & Onion & 8 & 06.66 \\
\hline h. & Sunflower & 8 & 06.66 \\
\hline i. & $\begin{array}{l}\text { Other vegetables (chilli, field beans, cluster } \\
\text { beans) }\end{array}$ & 7 & 05.83 \\
\hline j. & Sorghum & 4 & 03.33 \\
\hline \multicolumn{4}{|c|}{ 3. Summer } \\
\hline a. & Ground nut & 20 & 16.66 \\
\hline b. & Chilli & 13 & 10.83 \\
\hline c. & Onion & 10 & 08.33 \\
\hline 4. & Long duration crops & & \\
\hline a. & Sugarcane & 110 & 91.66 \\
\hline \multicolumn{4}{|c|}{ 5. Fodder crops } \\
\hline a. & Hybrid napier & 120 & 100 \\
\hline b. & Sesbania & 64 & 53.33 \\
\hline c. & Fodder Maize & 25 & 20.83 \\
\hline d. & Lucerne & 6 & 05.00 \\
\hline e. & Multicut fodder Sorghum & 5 & 04.17 \\
\hline f. & Fodder Cowpea & 4 & 03.33 \\
\hline g. & Guinea grass & 2 & 01.66 \\
\hline
\end{tabular}

Multiple responses are obtained

This could be because of the availability of grains and pulses at home from their own farms. As has been noticed there is a diversification in the region. The results are in conformity with the studies of Sabapara (2016) and Jadav (2018). More than half $(51.66 \%)$ of the dairy farm women were giving fodder more than thrice a day. All the 
respondents are cultivating high yielding Bajra Napier Hybrid. As mentioned earlier, this particular crop grows very fast and also yields very high. It has the potential to yield green fodder of 300 tons per hectare per year. Besides, the study area is an irrigated area and native green grass is available throughout the year. Availability of green fodder in adequate quantity could be the reason for the present finding. Also since most of the respondents are following stall feeding, and cattle sheds are usually located adjacent to their homes, the farm women fill the troughs as and when they go empty. About 21.00 per cent feed fodder twice and 27.50 per cent feed thrice a day.

More awareness about following scientific method of feeding could be the reason for the finding.

The results with regard to frequency of water given to the animals, 80.84 per cent of the dairy farm women gave water twice a day, 15.83 per cent of them gave water thrice a day and only 03.33 per cent of the respondents mentioned that water is given to livestock more than thrice a day.

Age of the livestock, body size, stage of the livestock (milking or otherwise) and the environment (mainly air temperature) influence the intake of water by livestock. However, it is observed that livestock is fed mainly with the green fodder which has considerable moisture in it. So, respondents thought providing water twice a day should suffice the water requirement of the animal. The research results are similar with the results of Sabapara (2016).

\section{Cropping pattern of the farms owned by landholders}

The research data shown in the Table 2 indicates the cropping pattern of dairy farm women in the selected region of the Gokak and Raybaghtaluks of Belagavi district. The multiple crops were grown in the kharif season in order of priority were maize $(80.33$ $\%)$, turmeric $(47.50 \%)$, vegetables \& green leafy vegetables $(09.17 \%)$, groundnut $(04.16$ $\%)$ and sorghum $(02.50 \%)$. The above findings are obtained because, Maize is a major crop grown in the area and covered under minimum support price in food crops by the government and no much worries in cultivating this crop. Turmeric is popular in the region due to its suitability to the region, less prone to pests and disease attack, good and almost stable market price and high demand.

Wheat is grown widely as a commercial crop in rabi season by 50.83 per cent followed by maize $(48.33 \%)$ because, Maize and Wheat are the major crops grown in the area is covered under minimum support price in the category of food crops by the government. Garlic (28.33\%), bengal gram (14.16\%), safflower $(08.33 \%)$, An equal per cent of the respondents $(06.66 \%)$ had grown groundnut, onion and sunflower. Very few (05.83\%) cultivated vegetables like chilli, field beans, cluster beans etc., Only 03.33 per cent cultivated sorghum were the other crops cultivated in the region. Reasons might be their suitability to the climatic and soil conditions of the region and Groundnut being leguminous crop also provides a residue in the form of nutritionally rich hay for livestock.

In summer season, main crops cultivated were groundnut (16.66), chilli (10.83\%) and onion $(08.33 \%)$, etc.

Sugarcane a long duration crop was grown by vast majority $(91.66 \%)$ of the respondents in the region. This is the major crop grown in the area because the area is well irrigated with favorable climatic conditions. Sugarcane is mainly used in jiggery \& sugar production. Further, Government of Karnataka has fixed the fair \& supporting price (FRP) for sugarcane. So, majority preferred this crop. 
The fodder crops grown in the region were hybrid Napier $(100 \%)$, sesbania $(53.33 \%)$, fodder maize $(20.83 \%)$, lucerne $(05.00 \%)$, multi cut fodder sorghum (04.17\%), fodder cowpea $(03.33 \%)$ and guinea grass $(01.66 \%)$. Fodder crops grown in the region were hybrid napier $(100 \%)$, sesbenia $(53.33 \%)$ lucerne (05.00 \%), multi cut sorghum (04.17\%), fodder cowpea $(03.33 \%)$ and guinea grass $(01.66 \%)$. Hybrid napier is cultivated by all the respondents because being a perennial crop it grows very fast and yields very high green fodder. It can be propagated easily from rooted slips or stem cuttings.

It requires regular irrigation, the study area is abundantly irrigated. Sesbania is a fodder shrub cultivated by more than half of the respondents. It is a legume crop and usually farmers of the region grow it as hedge crop besides getting fodder from it. Other fodder crops are cultivated by less than five per cent of respondents. Reasons could be lack of availability of seeds as well as lack of awareness about these crops. The above findings are in contrast to the findings of Kashappa (2010) and Bushetti (2017).

From the above study we could seen that, dairy farm women had some extent of awareness about scientific feeding practices and except few none of them were growing improved fodder crops to feed their animals. Hence, there is a necessity for organizing need based well designed trainings by concerned department to raise the awareness with regard to improved fodder crops to build a gap between requirement and availability, their by economizing and enhancing the cost of milk production in the country.

\section{References}

Anonymous, 2017.Milk production across countries, National dairy development board, https://www.nddb.coop.retrieved on 30 June, 2020.

Anonymous, 2019. Key results of $20^{\text {th }}$ livestock census-2019, Ministry of fisheries, animal husbandry and dairying, posted on 16 October, 2019, 6:26 pm by pib India (https://pib.gov.in) retrieved on 27/06/2020.

Bushetti, V., 2017.Impact of feed and fodder development programmes on livestock farmers of North Karnataka. M. Sc. (Agri.) Thesis, Univ. Agric. Sci., Dharwad, Karnataka, India.

Jadav, S.J., 2018. Prevailing feeding practices of dairy animals followed by dairy farmers in the operational area of dairy Vigyan Kendra, Vejalpur. Trends in Biosci., 11(14): 2467-2472.

Kashappa, N. M., 2013. A comparative study on dairy and non-dairy farmers in Belgaum district. M. Sc (Agri.). Thesis, Univ. Agric. Sci., Dharwad, Karnataka, India.

Biradar, N., Ramesh, C. R. and Pathak, P. S., 2003, Traditional livestock feeding practices in north Karnataka. Indian J. Trad.Knowled., 6(3): 459-462.

Sabapara, G.P., 2016. Feeding management practices of daily animals in coastal areas of Navsari district of India. Livestock research international. 4 (2): 88-93.

Parthasarathy, R., Hall, A. J.,2003.Importance of crop residues in crop livestock systems in India and farmer perceptions of fodder quality in course cereals. Field Crops Research. 84, 189-198.

\section{How to cite this article:}

Bhoomika, J. S. and Geeta P. Channal. 2021. Livestock Feeding Practices Followed by Dairy Farm Women in Belagavi District of Karnataka. Int.J.Curr.Microbiol.App.Sci. 10(02): 1599-1604. doi: https://doi.org/10.20546/ijcmas.2021.1002.190 